\title{
Rural Development Practices in Nepal
}

\author{
Chakra Bahadur Khatri \\ Department of Rural Development \\ Trichandra Multiple Campus, Tribhuwan University, Ghantaghar, Kathmandu, Nepal \\ cbbhattarai@gmail.com
}

\begin{abstract}
There is great values of rural development programmes in rural country like Nepal. The proper development programmes can get access as the milestone to the livelihood of rural poor and sustainable development of the Nation. This paper tries to carry out the sketch of rural development practices in Nepal. The paper is based on secondary data provided by the different government institutions. Most of the data are obtained from various periodic plans, books, articles, policies of governments. The relevancy of this paper goes to find out the past experiences and to adopt the future guideline for the formulation of effective, popular and sustainable programmes for rural development.
\end{abstract}

Key Words: Development, Integrated, Programme, Rural, Village

\section{Introduction}

Rural development is the key point of the development of any rural country with promotion of agriculture and allied activities. It is proved that the development of nation is possible by the rural development policies with the capacity of addressing the problems of rural people, women, isolated population from the mainstream of development and poor people. In the context of Nepal, Rural sector holding millions jobs, which is equivalent to more than 66 percent of the nation's workforce. Agriculture is responsible for over 27.04 percent of global gross domestic product (GDP) (CBS, 2017). Rural development comprises all aspects of rural areas, which are basically needed in a rural society. The term 'rural development' suggests overall development of rural areas with a view to improve the quality of life of rural people, especially for rural poor. Rural development is defined as a process leading to sustainable improvement in the quality of life of rural people especially the poor.

\section{Methods and Materials}

This study is based on the secondary data sources. Information for this study has obtained from various sources like; budget speech of different governments, economic surveys, different periodic plans of Nepal, manifestos of Nepali congress, policies and planning of the government of government, publication of rural development, different national and international journals, books related to rural development. The methods employed for the interpretation of the available data and information is mostly qualitative.

Some rural development programmes implemented by the government of Nepal in different time periods;

\section{Tribhuvan Village Development Program}

In Nepal, the first systematic and deliberate effort at rural development was made in 1952 with the inception of this program. It was multifaceted program embracing almost every aspect of the village community needs such as education, input supply for agriculture, drinking water, 
preventive health services, agricultural extension, cottage industry and co-operative development. The first Five Year Plan (1956-61) put a significant emphasis on this program (Regmi, et al, 2008). It consisted of three categories of program. The first category aimed at providing the minimum level of development and infrastructural facilities, the second category was to provide such facilities as improved seeds, fertilizer, horticulture, livestock development, and social services like primary school, first aid kits, drinking water in addition to the provision of the minimum level of development and infrastructural facilities, and the third category had an objective of providing scientific farming assistance, extension of health and maternity services, cottage industries etc (Adhikari, 1982).

However, it was very important programme and poor oriented along with the local support but the political system did not provide the fertile environment. As the result the this programme was closed and the Panchayat System imposed the Panchayat Development Program under the system of top-down planning in the place of this programme by the King Mahendra.

\section{Panchayat Development Program}

This program came into existence with the introduction of the partyless political system of Panchayat. Under this program, Panchayat Development Workers were required to work with the Village Panchayats and to help them in plan formulation and program implementation. Panchayat Development Land Tax was also introduced in 1966 to enable the local institutions to generate resources for rural development. Under this, the Village Panchayats were empowered to raise the land tax within its jurisdiction and retain a proportion of it for Village Development. This scheme was initially introduced in 12 Villages Panchayats of Jhapa district and subsequently expanded to include two other Village Panchayats of Morang district. It was however suspended in 1978 (Baskota, et al, 2008).

With the introduction of Panchayat System, Village Panchayats were set up in the rural areas covering approximately a population of two thousand each and Town Panchayats in a limited number of urban areas. Above them, seventy five District Panchayats comprising the representatives of the Village and Town Panchayats were created. Village Development workers were renamed as Panchayat Development Workers and Block Development officers as Panchayat Development Officer. The Panchayat Development officer was to serve as the executive secretary of the District Panchayats and the co-coordinator of rural development program at the district level (Baskota, et al, 2008).

\section{Jiri Multi-Purpose Development Project}

This programme was supported by Swiss government. It was launched in 1958 by Swiss association for technical support in Jiri of Dolkha District. Though it aimed at developing all sectors, it laid a more emphasis on agricultural development. The agriculture department was responsible for appointing the chief manager of the program and Home Ministry was responsible for coordinating the program. It was launched until 1970. After 1970, it was not given continuity since it was not part of the whole plan of the country (Bista, 2014). The Jiri Multi-purpose Development Project was started to provide necessary technical and other facilities for the improvement of the living conditions in the hill areas. The programme includes coordinated activities in such fields as agricultural extension, cooperative services, pastoral development, 
domestic science, general education and Panchayat training. Experience gained in this project would be useful for similar development efforts in other hill regions.

Table 1: Training Programme for the Pproject

\begin{tabular}{|l|l|l|l|l|l|l|}
\hline Financial Years & $\mathbf{1 9 7 0 - 7 1}$ & $\mathbf{1 9 7 1 - 7 2}$ & $\mathbf{1 9 7 2 - 7 3}$ & $\mathbf{1 9 7 3 - 7 4}$ & $\mathbf{1 9 7 4 - 7 5}$ & Total \\
\hline Training Centers & & & & & & \\
\hline Rampur & 436 & 427 & 396 & 509 & 367 & 2135 \\
\hline Chandragadhi & 474 & 566 & 490 & 472 & 528 & 2530 \\
\hline Nepalgunj & 573 & 550 & 497 & 264 & 560 & 2444 \\
\hline
\end{tabular}

Sources:- Forth Plan 1970

The training programme was held in three levels for the project;

Zonal Level Training

Arrangements would be made to provide training in Mechi, Narayani, Bheri, Bagmati, Lumbini and Mahakali zones during the Plan period by organizing seminars and conferences. One team would arrange 10 training camps and 2 conferences a year in one zone where a wider spectrum of local people can participate. During the Plan period 15,000 and 5000 persons would be given training by organizing 450 training camps and 90 conferences respectively.

District Level Training

District level training camps and conferences would be organized in 36 districts where zonal level training has not yet started. About 18,000 people will be given training in 1,800 training camps.

Women's Field Training

During the Plan period intensive training programmes would be conducted in various village and districts b setting up Women's Training and Extensive Centers. Under this programme 74,820 persons will receive training. To fill up the shortage of technicians and efficient women workers, training will be provided in the field of home science (at college level) and also to the women's workers, women's organization workers and to the women volunteers, 825 persons are expected to receive training under this programme (NPC, 1970).

\section{Agriculture Perspective Plan (APP)}

After restoration of the democracy 1990, the government of Nepali Congress implemented this programme during the Eight Five Year Plan. This programme was financially supported by the Asian Development Bank. The development works was began on September 1993 and 20 years APP was formulated (1994/1995 - 2014/2015) with the leading role of National Planning Commission (Khadka, 2066). The objectives of the programme were to accelerate the growth rate in agriculture, to alleviate poverty, to transfer the subsistence based agriculture into a commercial one, to expand opportunities for an overall economic transformation. The APP focused on green revolution based on technologies, high value production in both agriculture and non-agriculture sector high employment growth, focused on investment in human capital, physical and infrastructures, a package approach to development included of Terai, Hill, and Mountain, and huge level of women participation. The prioritized inputs of the programme were: Irrigation, fertilizer, technology, and road and electricity (Khadka, 2066).

\section{Small Farmer Development Program}


It was first launched in 1973 with the support of FAO/UNDP. It was launched as pilot program until 1975/76. Its main objective was to bring the small farmers into the mainstream of development. Under this program, the small farmers were provided with the loan for agriculture, animal husbandry, cash crops and technical support. Later it was launched under the extended program of Agricultural development Bank (Baskota, et. al, 2008).

Small Farmer Development Programmes (SFDP) intends to bring the rural poor farmer to the mainstream of development process. The main objectives of the programme was to raise social and economic status of small farmers and landless labourers including women (Shrestha, 2009).

\section{Integrated Rural Development Programs}

The rural development strategy developed by the World Bank during the 1970s was based on an integrated approach aimed at tackling rural poverty. Integrated Rural Development Progrmmes (IRDPs) typically contained similar components and emphasized increased agricultural productivity as the basis for rising rural income while recognizing the synergistic contribution of better education, health and other basic services to further improvements in propels' quality of life and their overall productivity. Project initiatives tried to achieve synergism between the various elements by using an integrated or 'central planning approach' to local development. Increase in production and productivity, equity and access to opportunities to earn income, in access to public services, in access to productive inputs, gainful employment and Self-reliance were the objectives of the programmes.

In Nepal it came into existence in the mid-1970s. It aimed at bringing about rural development by making a simultaneous effort to develop all sectors such as education, health, agriculture, drinking water, etc. Integrated hill development project was the first project of IRDP. It was launched with the support of Swiss government in 1974 in Dolkha and Ramechhap. The second project of IRDP was integrated rural development project launched in Nuwakot and Rasuwa with the support of World Bank (Regmi, et al, 2007).

The following details of some IRDPs could provide information to assess the implementation status. In addition, some other projects with the integrated approach were:

Integrated Hill Development Project:- the total cost of this project was Rs. First phase 20,253,000 second phase 7,11,139,000, and third phase 1,06, 300,000 donated/supported by the government of Switzerland and this project was run 16 years by three phases (1) $1974-80$, (2) $1980-85$ and (3) 1985-90. Total coverage population Sindhuplanchok and Dolakha 88,86,016 with the objectives to assist the local population and local institutions in efforts to improve their living conditions on a short and medium-term basis and to reestablish ecological equilibrium on sustainable basis as a precondition for their wellbeing in the long run. It included the major components agronomy, horticulture, livestock, veterinary, forestry, training, engineering, formal education, water management and energy, health, cottage industry, transportation.

Rasuwa-Nuwakot IRDP:- This programme was implemented in two phases. With the financial support of World Bank Rs. 1,35,985,000 for first phase (1976-83) and Rs. 1,57,000 for second phase Rs.1,57,000 (1984 - 85). The coverage population from Rasuwa and Nuwakot was 232,899 having the major objectives to increase production, productivity and employment in agriculture and off-farm activities with special emphasis on small farmers and to straighten 
institutional palpability to achieve this one a continuing basis, Human resources development and resource conservation, and participation and institutional development develop capacity to continuously build on their achievements and be increasingly self supporting and self-sustaining. The major components of the programme were agriculture, irrigation forestry, soil conservation health, transportation cottage and small scale industries, Panchayat development.

Mahakali Hills IRDP :- This programme was implemented with the financial support of Canada Rs. 161,400,000 during 1979 -85 and covered the population 3,46, 662 of Doti, Darchual, Bitadi, Dadeldhura districts having the objectives to raise agricultural production to levels whereby farmers could meet full family subsistence. The mejor components of this programme were agriculture, irrigation village cottage industry forestry, soil and water conservation, drinking works, rural works and Panchayat development

Koshi Hill Area IRDP:- UK supported programme was implemented with the cost: \$ 6.75 million. This programme was divided into three phases (1977-79), (1979-85) and (1986-1992). The coverage polplation of Sankhuasabha, Bhojpur, Terhathum, Dhankutha districts were $5,54,000$. The objectives of this programme were to strengthen local services and to help Government promote balanced economic, social development in order to gain maximum benefit from Dharan -Dhankuta road. Major components were agriculture, livestock, irrigation, forestry, credit and cooperative, cottage industry, communication water supply, health. Education, women's training.

\section{Community Forestry Programme}

The forest resource has made a significant contribution to economic and social development of the country. Besides, forests are indispensible as a life support system for women of the Hill Mountains, where agriculture, livestock and vegetation influence the ecology of the areas and lives of the local population. In Nepal two categories of forests are found based on ownership private and national forests. National forests are divided into five categories government managed forests, protected forests, communist forest, religious forest and leasehold forest In Nepal the community forest was formally introduced in 1978. Community forest is defined as the control, protection and managed of local forest by the local communities knows as user groups. The main objectives of the community forest are to achieve sustainable forest resources by converting accessible national forest into community forest in stages (Shrestha, 2009).

\section{Remote Area Development Program}

This progamme was an accumulation of small local development projects designed for remote and backward districts of the Himalayan region. A remote area development committee' consisting of non- official members of the districts, used to select the projects. It laid down the decisions of the Ministry of local development, which in turn would implement them through District and Village Development Committees. This program was launched in 2054/55 it covers 25 districts of the country. It is running in 25 districts at northern part of the country (Acharya, 2008). Under this programme, besides operating different projects in the remote and backward districts of the country, local leaders would be taken round on a Know Nepal tour and posters and brochures would be printed in local languages (NPC, 1976). 


\section{Micro Credit for Rural Women}

This project was implemented in 1993 and financial support was from the Asian Development Bank and Government Manila (ADB/N) of Nepal. The provided fund for this project by ADB was SDR 3.54 million. The main components of the projects can be specified as: Group formulation and training of women beneficiaries, institutional strengthening of selected NGOs and provision of credit to women. This project initially covered a period up to July 2002 and later it was extended bt two more years (Khadka, 2066). The objectives of the projects was to support GON in improving and enhancing socio-economic status of women and promote their participation and integrating in national development thereby contributing towards poverty reduction in Nepal. This programme also aimed to improve the income and employment of poor women in selected rural and urban areas.

\section{Village Development and Self-help Program (VDSHP)}

In 1996, VDSHP was introduced and became much popular among the people. The Build Our Village Ourselves (VODO) program was succeeded by the VDSHP with some additions in the previous VODO programme, which are:

- Strengthening the portfolio of VDCs by increasing VDCs block grant to NRs. 5,00,000,

- Granting authority to collect revenue locally and retain $75 \%$ of the land revenue,

- Developing human resources, maintaining $25 \%$ of the grant could be kept to increase village level expert like agriculture extension workers, village health workers, village technicians and teachers etc,

- Providing prize and penalty for good performing and bad performing VDCs (Shrestha, 2009).

\section{Rural Self-Reliance Programme}

This programme was introduced in 2047 BS in Nepal. This programmes run its activities by the help of NGOs and cooperative organizations to increase the economic status of poor people. This programme provides the credit fund of up to 7,50,000 by installment or direct according to the condition of business. This programme has also been undertaken to modernize and develop selfemployment vocational schemes. The programme in particular aims to upgrade the. traditional caste professions of the shoemakers (Sarki), tailors and flute players (Damai) and goldsmiths' (Sunar) by providing them with modern technical skills. This programme was implemented in 10 districts of the kingdom during the Eighth Plan. The programme also intends to train a total of 600 persons at the rate of 60 persons from each district annually (NPC, 1992).

\section{Women's Development Programme}

The Women's Development Programme is carried out to improve the socio-economic conditions of the poor and under-privileged women. The local branches of the Women's Development programme working under the Ministry of Local Development have been carrying out the work of organizing women of low-income groups and increasing public awareness through field workers. Under this programme, provision is made to make available collateral-free loans towomen organized in groups for undertaking income generating activities in agriculture, livestock cottage industries, and services business, etc through the commercial-banks. The Eighth Plan aims to increase the earning capacity of women and implement programmes that can raise the status of women, both socially and economically. During the Eighth Plan period, the Women Development Program expanded to 64 districts The main objective of this extension programme 
would be to activism the women who live below the poverty-line in various development works and make them self-dependent by improving their economic condition through the implementation of employment generating activities (NPC, 1992).

\section{Poverty Alleviation Programme}

Special efforts would, therefore, be made during the Eighth Plan for poverty alleviation. Correcting the faults of past for poverty alleviation the poverty alleviation programmes to be undertaken in the Eighth Plan would be so formulated and implemented that the relatively well to do families may not grab these benefits and the real poor ones would benefit directly or indirectly. Since, the poverty alleviation task is of multi in nature; it is essential for the programmes of all sectors to make a concerted effort to alleviate poverty. Hence, all the sectoral programmes would be directed towards poverty alleviation.

\section{Rural Community Infrastructure Development Programme}

Rural Community Infrastructure Development Programme (RIDP) be implemented in phasewise manner in 45 districts with the help of WFP. The main objectives of the programme was to improve food availability of the rural poor families, improvement and construction of community infrastructure in food deficit areas, strengthening the self-help capacity of rural community and to enhance the management capacity of the local bodies in implementing the programme. To increase the access of rural community in basic services, the programme such as linking rural roads with main roads and markets centers, community-based irrigation projects and river training to protect farm lands and farmers would be implemented. The programmes such as construction of small canals, pond construction, and maintenance in hill and terai districts, and mule tracks and tractor roads, river bank protection and small landslide control in mid-hill would be implemented. Programmes to reduce the malnutrition of the community would be implemented by mobilizing food under 'food for work programme' in food deficit area. This would help increase in income generation by creating employment in rural areas. This programme has the target of implementing 2,300 community based activities and food deficit 200,000 families would be benefited by participating in the food for work programme (NPC, 1997).

\section{Bisheshor among the Poor Programme}

The Bisheshor among the Poor programme was introduced in fiscal year 2056/57 as nationwide. Being based on B.P. Koirala's statement, 'our country is poor, our country is farmer's country, who helps to plough people, and who know the real condition of village people and policy which is for the betterment of the village is the programme of socialism. Nepali Congress initiated the programme 'Bisheshor among the Poor' at the time of his ruling. Rural ultra poor families, people with tore clothes, people whose children are not able to go school, those people who have not access on health treatment, landless, unemployed are the targeted groups of this programme. Considering the condition of bitter truth of elite class oriented economy of the country, this programme was introduced 75 districts at the same time targeting the ultra poor (Based on KII interview Mr. Prithi Prasad Sharma).

The objectives of this programme was organizing the people against poverty, and making people internally able, improved and self-reliance ( Swabalamban) The programme had extended its programme 421 working areas (VDC) between the 2056/57 to 2061/62. The programme 
organized 1 lakh people into groups. The numbers of groups were 6 thousands and in the 421 working areas under the direct supervision of social mobilize (Sharma, 2070).

\section{Ganesh Man Sing Shanti Aviyan}

The Ganesh Man Singh Shanti Aviyan (Ganesh Man Singh Peace Campaign) was initiated on September 23, 1999 it was the government's initiatives to provide economic assistance to conflict victims with the intensification of conflict and the simultaneous increase in the number of victims and conflict-related displacements, the government initiated a relief program for the Maoist victims called Ganesh Man Singh Shanti Aviyan (Ganesh Man Singh Peace Campaign) The program had a more systematic approach and tried to cover a wider range of victims and their needs. In conjunction with the campaign, the government established Victims of Conflict Fund in 2002. Besides the Home Ministry, the government also engaged the Ministry of Labour and Transport, the Ministry of Women, Children and Social Welfare and the Employment Promotion Commission to distribute the relief and implement other related programs (Advocacy, F. 2010).

\section{People's Embankment Program (Janatako Tatabandha Karyakram)}

This People's Embankment Programme was implemented based on people's participation, along with suitable programs for river control and landslide management in areas of Darchula District impacted by Mahakali River, including Khalanga, for protecting affected habitations and towns. The strategy on disaster management was implemented effectively. A disaster management was tabled at the Legislature-Parliament (Gov. of Nepal, 2071).

\section{Land Reform Programme}

The Birta Unmulan Ain that came into effect in 2016 B.S. eliminated the Birta Jaggas in 2016 Paush 1 B.S. and ended the practice of the feudal system of illegal encroachment of the land without paying the government the required revenue. After Land Survey and Measurement Act, 2019 B.S., came into effect, the maintenance of map based land records system was taken into practice. Similarly, the Land Related Act, 2021 B.S. came into effect with the objectives such as rapid economic development through the proper utilization of land resources, improvement of the livelihood of the land dependant peasants through the equal distribution of agricultural land, and providing them with the easy access of essential knowledge and required tools for the encouragement of farming and high productivity. In 2021 B.S., Land Reform Department established and the Land Reform Program carried out nationwide in 75 districts in three distinct phases: 16 districts in the first phase, 25 districts in the second phase, and 34 districts in the third phase.

The Guthi Corporation established in 2021 B.S. with the objective of Raj Guthi management. Under the provisions of Guthi Corporation Act, 2033, this corporation has been administering and managing all of the Raj Guthis till now. The Land Revenue Act, 2034, prepared for carrying out effective land management, provided the Land revenue Offices the authority to conduct the works conveyed by Mal Adda and Kosh and Tahisil offices, and to carry out the rest of the works operated by Land Reform Offices. With the commencement of Land Revenue Act, 2034, the broad land management area opened, such as collection of Land Revenue, Land Registration establishment of Land Revenue Offices. The Department of Land Revenue, which was working 
under the Ministry of Finance, was included under the Ministry of Land Reform and Management in 2044 B.S. (Ministry of Poverty, 2018).

One Home One Tree, One Village One Forest, and One City Many Parks Programme This programmes was launched during the fiscal year 2071 B.S., with the vision of conservation of forests and bio-diversity, it was launched as a national campaign thereby involving common people in afforestation and forest conservation.

\section{The President Chure Tarai Madhesh Presemalion Programme}

Government of Nepal has emphasized for its conservation since 1970 (Fourth Five Years Plan) and started Rastrapati Chure Conservation Programme with NRs 250 million year marked budget from the fiscal year 067/068. Ministry of Forests and Soil Conservation is leading and implementing this programme in 27 districts through its departments i.e. Department of Forests and Department of Soil Conservation and Watershed Management. To manage Chure area by establishing linkages with upper and lower belts and to make The President Chure Preservation Programme more effective by framing an integrated action plan for watershed and river systems, 'The President Chure Tarai Madhesh Presemalion Programme' was formulated and implemented with a new vision and institutional mechanism. This project was started 2015 AD With the project title of Landslide Inventory, Characterization and Engineering Design for Mitigation Works of Chure Area in Ten Districts. It had covered 10 district of the Chure region as project locations, the financial aspect of this project was US\$ 84,000, and the project was supposed to end at 2016. The main objective of the project was to prepare landslide inventory, landslide susceptibility map of selected Chure area of ten districts viz; Makwanpur, Bara, Rautahat, Udaypur, Sindhuli, Siraha, Saptari, Sarlahi, Mahottari and Dhanusha (Gov. on Nepal, 2071).

\section{Let's have a Doctor in Our Village Program}

This was very popular and milestone programme for the rural development adopted by the governments of Nepali Congress. Additional vacancies of doctors would be created in all district hospitals and first-aid health centers. Basic health laboratory test service would be made available gradually from health centers. The objectives of this programme was to send the technical human resources to rural areas, a special plan health human resources for remote areas would be executed and health service will be provided to remote areas Gov. of Nepal, 2071).

\section{Built Our Village Ourselves Program}

This program was implemented in the fiscal year 2051/52 each Village Each year government was providing an equal block grant of 300000 for all the VDCs and Municipalities and those local institutions had given authority to implement development programmes with active participation from the local communities and later by fiscal year 2052/53 the very amount was increased by the five laks (Shrestha, 2009).

This programme was started nation-wide having some aims;

- To strengthens the village local government with authorities and resources,

- To reduce dependency of the villages on the center for small development activities, and

- To regenerate the feeling of self-reliance to the local communities. It was a major policy breakthrough in the history of rural community development (Regmi, et al, 2007). 


\section{Production Credit for Rural Women}

Production Credit for Rural Women (PCRW) is a poverty alleviation project of UNCIEF targeting women. PCRW was first introduced in 1982 in five Districts of Nepal. The programme was implemented by women workers in the implemented districts. The Nepal Rastra Bank through three participating banks, such as Agricultural Development Bank, Nepal Bank LTD, and Rastriya Banijya Bank channel the credit. IFAID provided assistance to Women Development Division to implement this programme in 1988. The programme was started the project is in operation through Women Development Welfare Department of Ministry of Women, Children and Social Welfare. Between the years 1982 to 2000, the programme is being implemented in 75 districts covering more than 540 DVCs and 75 unit offices.

The basic objective of the PCRW is to improve the social and economic status of women by providing credit facilities based on group collateral.

\section{Special Area Development Program}

This program was launched in 2055/56 including the 25 district of the country. Under the ministry of local development it emphasized to the rural road, Irrigation, development of livestock and herbal plants, social mobilization and employment with income (Bista, 2014).

\section{Decentralization Programme}

The importance of the Panchayat system in securing mass support for national and local development programmes and the need for decentralization to further generate support have already been mentioned. In order to generate greater public support, to coordinate loc level activities and to effectively implement plans, more responsibility needs to be given the 3,600 Village, 75 District and 14 Zonal Panchayats. The implementation of decentralization, greater authority would be given the local and District Panchayat. The development of health, education, agriculture, roads and similar functions at the local level would be shifted gradually to the District Panchayats. The District would, in turn, delegate many of these functions to the village Panchayats. In order to achieve the objectives of decentralization, District administration would be reorganized and staff upgraded and given the necessary training. The decentralization progrmme would therefore be undertaken in three phases: preliminary, transitional, permanent.

\section{Tribhuwan Gram Bikas Namuna}

This program was started by institutional help of the help of America and India. In this program there was gram development board in center, block development office department level and village development activist. Targets of this program were; to make community self dependent swabalambi by participating people in community development, to develop the rural development related organization by mobilizing the economic sources of rural area, to work as helper of development of agriculture, health, and rural industry by establishing rural development center.

\section{Objectives of Tribhuwan Gram Bikas Namuna}

To participate of the people for the program and select the leadership and increase the scientific knowledge to met own necessities were the objectives of this programmes. 


\section{Irrigation Development Programmes \\ Begmati Irrigation Project}

This project is expected to eventually command 68,000 hectares utilizing a barrage in Bagmati River between Janakpur and Narayani zone within Sarlahi, Rautahat and Bara districts to increase output enormously. This project constructed into two phases During the Sixth Plan, it was originally planned to command an area with extensive irrigation as part of the first phase of the projects in development and during the Seventh Plan it fulfiled the target of first phase commanding an area of 32,000 hectares consisting of 12,000 hectares in Sarlahi District and 20,000 hectares in Rautahat district (NPC, 1980).

\section{Sunsari Morang Irrigation Project:}

This project was completed in 1975 aiming to extend the irrigational facilities of an area of 66,000 hectares of Sunsari and Morang Districts but because of the different serious problems nearly an area of 33,000 hectares had been fulfilled to irrigate successfully and this project aiming to make more appropriate and scientific project was further initiated in the fiscal year 1979/80 (NPC, 1980).

\section{Narayani Irrigation Development Project}

By the end of the Sixth Plan the Narayani Irrigation development Project has been consisted of gross area of 31,400 hectares of Bara, Parsa and Rautahat of Narayani zone and net irrigable area of 8,700 hectares in Rautahat District aiming to complete the additional target of an area of 4,700 hectares to fulfill the reformed type of irrigational facilities intensively This project carried over into the first year of the Seventh Plan consisting of the completion of the part of the phase II of the Sixth Plan. Based on the experiences and performances of the phase II, the project would target for implementing the irrigational facilities and for completing the feasibility study of phase III of the project, renovation of the completion of the feasibility of secondary canal, shallow tube well development, river control and so forth (NPC, 1980).

\section{Mahakali IrrigationProject}

The project with a gross command area of 6,600 hectares is located in the Kanchanpur District of Mahakali zone in the Far-western Development Region claiming the rights of the use of Mahakali rivers divided from the Sharada barrage with India. This project was initiated in the fiscal year 1980/81. 5,000 hectares of land would be provided the irrigational facilities and develop an additional area of 1,600 hectares with the objectives of the Seventh Plan improving the reliability of water deliveries to the farmer. After completion of the project the area of 6,600 hectares would be irrigated intensively.

\section{Chitawan Irrigation Project}

This project located at Chitwan District of Narayani zone in Central Development Region was initiated in the fiscal year 1974.75 Commanding an area of 11,700 hectares. This project comprises Narayani lift irrigation consisting of the construction of an area of 4,700 hectares, 3,900 hectares of land reconstruction of Khageri canal, 600 hectares of land of Panch Kanya water irrigation construction, 1900 hectares of land of Lother Rapti canal construction, 600 hectares of land of Pithuwa canal renovation and agricultural development programmes at the same time. 


\section{Mohana Irrigation Project, Dhangadi}

This project is located in Kailali and Kanchanpur district of Mahakali and Seti zones in FarWestern Development Region, This project had the target of irrigating intensively of an additional area of 3,500 hectares consisting of 1,200 hectares of land of Kailali District, of Mohana (Mahali) river water and 2,300 hectares of land of Kanchanpur District.

\section{Hill Irrigation Project: First Phase}

Under this project intensive irrigation facilities have been provided to an area of 4,100 hectares in the Western Development Region consisting of an area of 1,280 hectares at Bijayapur, Kaski, 580 hectares If land in begnastal, Kaski; 380 hectares of land in Hyangja, Kaski; 850 hectares of land in Chapakot tar, Syangja; 480 hectares of land in Rampur fant, Palpa; 300 hectares of land in Phalewas, Parbat and 280 hectares of land in Bulingtar, Nawalparasi (NPC, 1980).

\section{Hill Irrigation Project: Second Phase}

Under this project intensive facilities would be provided to the target of an area of 4,400 hectares in Doti, Bajhang, Aachham, Bajura Districts of Seti zone consisting of 1,280; 1,280; 1,780; 440 and 900 hectares of land respectively. This project was initiated in the fiscal year 1984/85 (NPC, 1980).

\section{Conclusion}

Rural development is inevitable for the holistic development of the nation based on its agricultural nature. In Nepal there are many more rural development programmes launched by the different governments in different time. Most of the rural development programmes are related to the rural infrastructure development like land reform, water, electricity, agriculture, social-cultural issues etc.

The programmes implemented by the governments in Nepal are very important for the rural development and national development as Nepal is rural country. The study has also shown the high potentiality of economic growth through rural development. But on the other hand, the implemented policies and programmes of rural development in Nepal have not been able to address the real problems of rural poor people. Some of the programmes are considerably good but the next government does not continue. It is strongly necessary to implement the pro-poor oriented and geographically suitable rural development policies.

\section{References}

Acharya, B. R. (2008). Dimension of rural development in Nepal. Dhaulagiri Journal of Sociology and Anthropology, 2,

Adhikari, S. P. (1982). Integrated rural development in Nepal. Kathmandu: Sahayogi Press. Advocacy Forum, (2010 AD) The painful tail of interim relief in Nepal,discrimination and irregularities. Kathmandu: Advocacy Forum.

Baskota, S., Sapkota, K. Sapkota, B.,Shree, B. and Khadka, B. (2008). Rural development: theories, principles and approaches. Kathmandu: Sujata Publication.

Bista, S. K. (2014). Rural development in Nepal: past efforts and current approaches. Kathmandu: Nepal Constitution Foundation.

Central Bureau of Statistics (CBS) (2017). Central Bureau of Statistics. 
Government of Nepal. (2071). Policy and Programmes of the government of Nepal 2071. Kathmandu: Office of Prime Minister and Council of Ministers.

His Majesty of Gov.of Nepal. (2049). Budget speech, (2049, Ashad, 31). Kathmandu: Ministry of Finance.

----- (2050). Budget speech, (2050, Ashad, 27). Kathmandu: Ministry of Finance.

------ (2051). Budget speech, (2051, Ashad, 31). Kathmandu: Ministry of Finance. (2053). Budget speech, (2053, Ashad, 26). Kathmandu: Ministry of Finance. (2055). Budget speech, (2055, Ashad, 26). Kathmandu: Ministry of Finance. (2056). Budget speech, (2056, Ashad, 27). Kathmandu: Ministry of Finance. (2057). Budget speech, (2057, Baisak 03). Kathmandu: Ministry of Finance. (2002). The tenth plan (2002-2007). Kathmandu: National Planning Commission. (2004). National agriculture policy 2004. Kathmandu: Ministry of Agriculture. and Livestock Development (2005). Water policy, 2005. Kathmandu: Ministry of Water Resource and Environment. (2005). National micro-finance policy 2005. Kathmandu: Ministry of finance. (1997). The ninth plan (1997-2002). Kathmandu: National Planning Commission. (1992). The eighth plan (1992-97). Kathmandu: National Planning Commission.

Khadka, G. (2066). Rural development policies and strategies. Kathmandu:

Sunlight Publication.

Nepal Planning Commission (NPC), (1956). The first plan, 1956-1961. His Majesty's

Government of Nepal, Kathmandu: National Planning Commission.

NPC, (1970). The forth plan, 1970-1975. His Majesty's Government of Nepal, Kathmandu: National Planning Commission.

-NPC, (1976). The fifth plan, 1975-1980. His Majesty's Government of Nepal, Kathmandu: National Planning Commission.

NPC, (1980). The sixth plan, 1980-1985. His Majesty's Government of Nepal, Kathmandu: National Planning Commission.

NPC, (1992). The eighth plan, 1992-1997. His Majesty's Government of Nepal, Kathmandu: National Planning Commission.

NPC, (1997). The ninth plan, 1997-2002. His Majesty's Government of Nepal, Kathmandu: National Planning Commission.

Regmi, N., Koirala, N. \& Khatri, C. (2008). Basic knowledge of rural development. Kathmandu: Asia Publication.

Sharma, P. (2070). Bisheshor Among the Poor Programme: Relevancy and Necessity. Shrestha, M. (2009). Community Development. Kathmandu: Quest Publication.

World Bank (1997). Rural development: Vision to action: A Sector Strategy. Washington DC: The World Bank.

World Bank (1889). Nepal social sector strategy review, volume II. Washington DC: The World Bank. 